\title{
PRODUCTION ASSISTANCE FOR UMKM BATIK KENANGA MEKAR
}

\author{
Meiliyah ARIANI ${ }^{*}$, Ifah ROFIQOH ${ }^{2}$ and Zulhawati ZULHAWATI ${ }^{3}$ \\ ${ }^{1}$ Universitas Prof. Dr.Moestopo (Beragama) \\ ${ }^{2,3}$ Universitas Teknologi Yogyakarta \\ *meiliyahariannie@yahoo.co.uk
}

\begin{abstract}
Training aims to develop skills, knowledge, and attitudesin the process of increasing self-potential according to the needs and potential of the region. One of the useful trainings to develop regional potential is training batik making. Where the Annual Village, District Umbulharjo is one of the areas producing Craft Tourism. Kampung Tahunan has several studios that create batik products and jumputan fabrics. The potential of the area as well This is the culture of the Indonesian nation that must be preserved, namely by held a written batik training. Batik Kenanga Mekar is a group of beginner batik craftsmen in Tahunan Village, Umbulharjo District. This village is one of the Cultural and Tourism Conservation Areas in the city of Yogyakarta. Geographically, the Tahunan Village area is strategic so that in 2011 it was inaugurated as a Cultural Tourism Village. As a Tourism Village, there are still many things that need to be addressed by adjusting the one in the vision and mission of the Medium Term Planning (RPJM) which is to improve the welfare and empowerment of the community. To support this, the potential of the community must be maximized, so that the devotees develop one of the existing potentials by empowering the local community which will later improve the welfare of the community. The artistic potential is high and creative, besides that the community still has a lot of time left that has not been utilized so that written batik can be developed.
\end{abstract}

Keywords: Batik, Production Assistance, Empowerment

\section{BACKGROUND}

Basically, batik activity is an activity to preserve culture and is still a promising business opportunity. Batik is an ancestral craft that must be preserved. Batik is a craft that has high artistic value and has been part of Indonesian culture for a long time. Batik is a work of the nation that holds the noble values of the Indonesian people's culture. Since centuries ago, batik has been used by women and men who remain closely related to the lives of the Javanese, Madurese and Sumatrans. spread over various countries.

Batik is an Indonesian cultural heritage that has no doubt about its authenticity, as evidenced by the award of batik as one of the world's cultural heritages produced by the Indonesian nation by UNESCO on October 20, 2009. UNESCO's recognition was given mainly because of the assessment of the diversity of batik motifs which are full of deep philosophical meanings. In addition, the government and people of Indonesia are also considered to have taken concrete steps to protect and preserve this cultural heritage from generation to generation.

At the beginning of the batik award by UNESCO, people did flock to wear batik to show their nationalism. But the sad thing is that what they use is batik printing or stamped batik. People buy batik printing because the price of batik printing is much cheaper than batik. And that phenomenon is what makes the batik printing industry rampant.

The award that was obtained from UNESCO was written batik, not printed or stamped batik. And this is what causes the wrong understanding of this batik award. So it's more about the process of making batik, which is valued as a human heirloom. Batik is a work of humanity that is full of various local wisdoms. Not only from the motive, but also the manufacturing process. For example, now we do not understand what indigo is. In fact, this is a natural dye that produces blue color from the indigofera plant, or also red noni. Now it is rampant chemical dyes that actually damage the environment. This is what we have to fix.

Regarding the misunderstanding about the preservation of written batik, if something goes wrong, this could backfire. The worst thing would be if UNESCO revoked the recognition of written batik because of the failure in its preservation.

In this mentoring activity, it is carried out in the Yogyakarta Annual Village which has creative cultural and economic potential which is managed by the community of each village as a cultural buffer for the city of Yogyakarta. The Annual Village in Umbulharjo District has a Tourism Village called the Annual Tourism Village. Annual Tourism Village is one of the developing tourist villages in the city of Yogyakarta. In addition to being a tourist village that has potential in the arts and culture field, Annual Village also has other potentials that are unique in the historical value of its development. As a Tourism Village that was formed in 2010, the Annual Village has potentials that have been formed in a short period of time. Annual Tourism Village has several interesting tourism potentials, including: cultural tourism and craft tourism.

In addition to offering tourism villages and cultural heritage, the Tahunan Village also offers other potential or resources owned by the local community. One of the potentials of the community that has been developed currently is hand-drawn batik. In addition, Yogyakarta was also named the world's batik city on October 8, 2014. The opportunity for this hand-drawn batik development activity can provide added value to the people of Tahunan Village. In addition, hand-drawn batik can also be used as a home industry which is expected to help improve the family's economy.

The training to improve the skills of writing batik and stamping in the form of mentoring was carried out for 
three months, starting from March 2011 to May 2011. The training activity was held on Monday (1/3/2021) at the PAUD Nursiwi Building, Tahunan Village, Yogyakarta. The training started with writing batik with canting. Meanwhile, the new stamped batik training session was held after the written batik session was over. It is intended that participants focus more on each process from beginning to end.

This written batik training was once carried out by housewives in RT 19 and RT 20, Tahunan Village, but currently, batik activities are no longer carried out because there are several problems. Based on the mutual agreement between the proposer and the partners, some of the issues that need to be resolved during the service implementation assistance are:

1. The entrepreneurial spirit is not yet maximized. Mothers do not yet have an entrepreneurial spirit. Because so far there has never been any formal training on entrepreneurship.

2. Limited costs for doing batik training. The interest of the mothers to learn batik sustainably manner is very high, but the limited funds to make the training have not been continued. So far, this group of mothers has only relied on sponsors from servants or independently from contributions to buy equipment.

3. Limited professional teaching staff. Limited funds make the training only incidental so that it has not been able to bring in professional assistants.

The implementation of the problems that these mothers have can be overcome by looking at the existing potential, namely:

1. By providing training and entrepreneurship assistance. One of the objectives of batik training is to empower mothers to be economically independent. One of the efforts made to increase the enthusiasm and motivation of mothers in learning batik to increase economic independence is to provide entrepreneurship training. With this training, it is hoped that the entrepreneurial spirit and spirit of women can grow and develop.

2. Assistance by professional teaching staff on an ongoing basis. The group of women learned to make batik because there was training from a community service program that the service team had done. With continuous assistance and professional teaching, it will increase creativity and innovation so that it can produce batik that is worth selling.

The following are the results of the Production Assistance training activities for Batik Kenanga Mekar SMEs:

\section{METODE}

Based on these problems, the service and partners agreed to solve these problems through training, mentoring and evaluation. The community empowerment model to overcome the above problems uses the Participatory Rural Appraisal (PRA) method. The consideration for choosing this method is that it is partners who face the problem, therefore the involvement of partners in determining the solution to the problems encountered and their resolution is very necessary. The implementation of the method is divided into three stages, namely preparation, implementation, and preparation of reports.

1. The preparation stage begins with counseling on the development of motif designs and the diversification of processed batik fabrics.

2. The next stage is the implementation stage which includes training and mentoring activities consisting of:

a. Assistance in the development of motif designs and diversification of processed batik products

b. Assistance for written and stamped batik products.

c. Assistance in strengthening product diversification through increasing roles the younger generation and PKK mothers.

3. The last stage is the preparation of reports, posters and scientific articles for publication purposes.

\section{RESULTS AND DISCUSSION}

Based on the analysis of the partner's situation and problems, the output targets resulting from science and technology program activities for the community in the form of women's empowerment are:

1. Formation of an entrepreneurial spirit and spirit, at the end of this service activity, partners must be able to show the following results:

a. The trainees have a change in thinking power to become entrepreneurs by changing their mindset, being action-oriented, taking risks, not giving up easily, being creative, innovative and, confident. With this change, it is hoped that women will be ready to become batik entrepreneurs independently.

b. Have competence in developing business, increasing productivity and, business management.

2. Can make batik, at the end of this activity must show the final results in the form of;

a. Can make batik with chemical coloring.

b. Increase creativity and innovation to produce batik that is worth selling.

3. Formation of Batik Craftsmen Group or Joint Business Group (KUBE) Batik, at the end of this activity, must be able to show the following final results;

a. A professional Batik Tulis Joint Business Group was formed that is ready to produce batik that is worth selling

b. The Batik Tulis Joint Venture Group is ready to implement the marketing mix through product design strategies, pricing strategies, distribution strategies and, marketing communication strategies 
c. Have the motivation to continue to learn and develop business, seek market opportunities and build networks so that they can become economically independent entrepreneurs

d. Build a network by registering with the Ministry of Trade and Industry so that joint exhibitions and joint marketing with other Small and Medium Enterprises can be included

\section{CONCLUSION}

The intentions of women in the Tahunan Village for entrepreneurship are good. From the results of interviews, observations and, assistance during community service to find out the problems faced by informants, $60 \%$ of the training participants are ready to become batik craftsmen who are ready to be sold. The rest of the entrepreneurship training participants need further strengthening.

Those who are not ready to become entrepreneurs because they are not from an entrepreneurial family. Role stress is a consideration in determining the intention to become an entrepreneur. The trainees are still hesitant because of the various obstacles that will be faced and are worried about the prospects of written batik in the future, especially in the face of technological advances and the entry of foreign products.

The participants of the mentoring activity were very enthusiastic because it was a new thing for the group. After all the Paguyuban Batik Kenanga Mekar group had never held batik stamp training. Because so far Kenanga Mekar is still engaged in the field of hand-drawn batik and jumputan. It is hoped that with this new thing the ability to make batik of members will increase and help the economic recovery of the community affected by COVID-19.

\section{ACKNOWLEDMENT}

The authors would like to thank Universitas Teknologi Yogyakarta and Universitas Prof. Dr. Moestopo (Beragama) for financial support and opportunity given to conduct this community service.

\section{REFERENCES}

Chasan, Mas'ud, 2005, Sukses Bisnis Modal Dengkul, Pustaka Pelajar
Harefa, Andrias, dan Eben Ezer Siadari, 2006, The Ciputra Way: Praktek Terbaik Menjadi Entrepreneur Sejati, Jakarta: Elex Media Komputindo

http://inspirasitabloid.wordpress.com/2010/07/27/kubekelompok-usaha-bersama-sebagai-model-untukpengembangan-pemberdayaan-masyarakat diakses tanggal 15 Maret 2015

Nurcahyo Bagus, Peluang Bisnis dan Kewirausahaan, www.wirausaha.com

Nurudin Siraj, Marketing Strategi and Marketing Plan, www.marketing.com

Suryana, 2003, Kewirausahaan, Jakarta: Salemba Empat

Joyce, Bruce, Marsha, Weil, and Beverly Showers. (1992). Models of Teaching.

Boston: Allyn and Bacon.

Ketut, Sunarya, 2000. Kuliah Kerajinan Batik I. Yogyakarta: UNY.

Mukminan. (1998). Belajar dan Pembelajaran. Yogyakarta: IKIP Yogyakarta.

Luhur Hertanto. 2009. UNESCO Akui Batik Milik Indonesia

- detikNews. Dari http://www.detiknews.com/

Perkembangan Batik di Indonesia. (http://id.88db.com/id/ Knowledge).

Adi Kusrianto., 2013, Batik Filosofi, Motif Dan Kegunaan, CV.ANDI OFFSET,Yogyakarta

Aep S. Hamidin., 2010, Batik Warisan Budaya Asli Indonesia, Penerbit Narasi, Yogyakarta

Ari Wulandari., 2011, Batik Nusantara Makna Filosofis, Cara Pembuatan, Dan Industri Batik, CV. ANDI OFFSET, Yogyakarta

Asti M \& Ambar B. Arini., 2011, BATIK-Warisan Adiluhung Nusantara, CV. ANDI OFFSET, Yogyakarta .................,2018, Pedoman Pelaksanaan Pengabdian Kepada Masyarakat, DPPM UII, Yogyakarta 